УДК 504.4.054:628.357.4

(C) 2012

Булавенко Р. В., кандидат сільськогосподарських наук,

Степова О. В., кандидат технічних наук,

Рома В. В., стариий викладач

Полтавський національний технічний університет ім. Юрія Кондратюка

\title{
ДООЧИЩЕННЯ СТІЧНИХ ВОД ПІДПРИЄМСТВ ХАРЧОВОЇ ПРОМИСЛОВОСТІ ЗА ДОПОМОГОЮ СПОРУД БІОПЛАТО
}

\section{Рецензент - доктор технічних наук, професор В. О. Бондар}

\begin{abstract}
На основі вивчення існуючих методик фітотехнологій, зокрема застосування вищих водних рослин у конструкціях біоплато та інших новітніх методик, було розроблено ефективну, екологічну технологію доочищення стічних вод підприємств із переробки молочної продукиї з метою повторного використання їх на підприємстві. Запропоновано двоступінчасту конструкиію біоплато з вищими водними рослинами (очерет звичайний, комим озерний, рогіз вузьколистий, рогіз широколистий, аїр болотний). Розроблена конструкція біоплато 3 вищими водними рослинами для доочищення стічних вод молокозаводу, з наступним їх використанням їх для потреб підприємства.
\end{abstract}

Ключові слова: фітотехнології, фіторемедіація, стічні води, біоплато, вищі водні рослини, молочна промисловість.

Постановка проблеми. Втручання людини в природні гідрологічні цикли проявилося у розрегулюванні природного стоку шляхом створення гігантських водосховищ, забруднення промисловими та побутовими відходами, пестицидами, отрутохімікатами та добривами.

Екологічний стан водних об'єктів Полтавщини (як і України в цілому) свідчить, що більшість річок і водотоків знаходяться у поганому стані: їх русла замулюються, заростають водною рослинністю. Передусім це стосується малих річок, протяжність русел яких не перевищує 2530 кілометрів.

Нині охорона малих річок зводиться до заборони будь-якої діяльності в заплаві та штрафних санкцій до промислових об'єктів і фізичних осіб, які скидають забруднені води до річкової мережі. Проте це не вирішує ні проблеми їх охорони, ні проблем, пов'язаних 3 умовами проживання людей на берегах річок. Найбільш реальний шлях - впровадження (за еколого-економічними критеріями) водоохоронних заходів у заплаві використання елементів фітотехнологій.

На даний час немає методики використання фітотехнологій, за якою можна було б визначи- ти, які $з$ них необхідно впровадити в систему захисту малих річок і які б враховували компоненти довкілля. Найбільш повно відпрацьована методика використання різних модифікацій біоплато О. П. Оксюк і Ф. В. Стольберга для впровадження їх на каналах, але для річкових систем підхід повинен бути дещо іншим.

За наказом Міністерства охорони навколишнього природного середовища України Харківською національною академією міського господарства спільно 3 Українським науководослідним і проектним інститутом «Водоканалпроект» у 2005 р. створений проект нормативного документа «Екологічні вимоги і рекомендаціях по створенню і експлуатації очисних споруд фітотехнології», узгоджений зі всіма зацікавленими міністерствами і відомствами. Документ визначає область застосування фітотехнології як метод доочистки стічних вод відповідного складу, віддаючи перевагу господарсько-побутовим і іншим стічним водам, що містять розчинені органічні речовини природного походження, нафтопродукти з концентраціями близько 20 мг/дм ${ }^{3}$, а також від звалищ твердих побутових відходів.

Основним забрудненням підприємств харчової промисловості $є$ органічні речовини, тому розробка методики застосування фітотехнологій для доочищення стоків цих підприємств із повторним використанням очищеної води на виробництві сприятиме зменшенню навантаження на водні об'єкти й, відповідно, раціональному використанню водних ресурсів та їх охороні.

Виходячи 3 наведеного, розробка методів застосування вищих водних рослин у очищенні та доочищенні стічних вод молокопідприємств залишається актуальною.

Аналіз основних досліджень та публікацій, у яких започатковано розв'язання проблеми. Традиційні очисні системи підприємств із виробництва молочної продукції не задовольняють більшості критеріїв щодо якості води, яка скидається в водні об'єкти. Це вимагає застосування нових, 
ефективних, недорогих водоохоронних методів. Серед цих методів - методи фіторемедіації за допомогою вищих водних рослин.

Вищі водні рослини, такі як комиш, очерет, рогоз, володіють здатністю видаляти 3 води забруднюючі речовини: біогенні елементи (азот, фосфор, калій, кальцій, магній, марганець, сірку), важкі метали (кадмій, мідь, свинець, цинк), феноли, сульфати, нафтопродукти, синтетичні поверхнево активні речовини (СПАР), і поліпшувати такі показники органічного забруднення, як біологічне споживання кисню (БСК) і хімічне споживання кисню (ХСК). Ці рослини є місцевими видами і тому добре адаптовані до наших кліматичних умов $[1,2,6]$.

Прогресивним розвитком методів природного біологічного очищення $є$ біоінженерні споруди типу біоплато, які у світовій практиці отримали назву Constructed Wetlands. Біоплато - це штучно створені системи очищення, що нагадують біоставки, розташовані каскадом і побудовані 3 урахуванням оптимальних фізико-хімічних та біологічних факторів процесу очищення. Існують різні класифікації систем очищення стічних вод на спорудах типу біоплато. Розрізняють такі категорії споруд біоплато: поверхневі, горизонтальні інфільтраційні, вертикальні інфільтраційні й змішаного типу. Різні типи біоплато мають свої особливості, що і створює можливість очищення в них різних категорій стічних вод $[1-3,5]$.

Літературні дані свідчать про ефективність очищення та доочищення води в біоплато і доведення показників якості води до нормативних значень $[5,6]$.

Природність процесу $є$ істотною перевагою споруд фіторемедіації порівняно, наприклад, із біологічною очисткою в аеротенках, де процеси біодеструкції інтенсифіковані й суттєво відрізняються від природних $[1,3,5]$.

Перевага використання біоплато:

- будівництво споруд не потребує висококваліфікованих працівників і виконується місцевими будівельними організаціями з традиційними технічними засобами;

- експлуатація не потребує витрат електроенергії, хімічних реактивів;

- строк роботи БІС без капітального ремонту до 30 років і більше, поскільки це - самовідновлюча система;

- в період експлуатації споруд нагляд за ними може виконувати один працівник із середнім рівнем кваліфікації;

- термін введення в дію БІС - через 2-6 місяців після початку будівництва [4-6].
Біоінженерні очисні споруди працюють на протязі всього року.

Використання прогресивних технологій, заснованих на дії вищих водних рослин, у наш час $є$ екологічно прийнятним і економічно найбільш перспективним напрямом у системі очищення та доочищення стічних вод. Їх впровадження на підприємствах із переробки молочної продукції може сприяти відновленню або поліпшенню екологічної ситуації в регіоні.

Метою досліджень $є$ аналіз можливості застосування біоплато для доочистки стічних вод підприємств із виробництва молочної продукції.

Матеріали досліджень. Розробка конструкції біоплато для доочищення стічних вод від підприємств із переробки молочної продукції.

Результати досліджень. Користуючись даними Полтавського регіонального управління водних ресурсів, можемо сказати, що у Криву Руду скидають стічні води кілька промислових об'єктів: Кременчуцький міськмолокозавод; ЗАТ «Джей Ті Інтернешнл Україна», 3АТ «Кременчуцька кондитерська фабрика», кар'єроуправління «Кварц». Контроль за якістю води в річці Крива Руда показав, що існує перевищення ГДК за трьома основними показниками: ХСК, амоній - іони та загальне залізо. Вода в даному водному об'єкті характеризується як дуже брудна (IV клас якості).

До складу органічних забруднень міськмолокозаводу входять, головним чином, вуглець, водень, кисень та азот. У результаті біохімічного окислення органічних сполук, що містяться в стічних водах, із водойм поглинається велика кількість кисню, в результаті чого фауна і флора водойм може загинути.

Стічні води, що утворюються на підприємствах молочної промисловості, характеризуються високою забрудненістю органічними речовинами (3 г ХПК/л), а за неповної утилізації відходів виробництва, передусім сиркової та сирної сироватки, й значно більше (до 6-8 г ХПК/л). Висока забрудненість стічних вод підприємств молочної промисловості, а також нерівномірність їх надходження в багатьох випадках призводить до перевантаження та незадовільної роботи як міських, так і заводських очисних споруд.

Із метою досконалості та раціональності використання водних ресурсів даних підприємств, зменшення антропогенного впливу на річку Крива Руда пропонується застосовувати метод повторного використання очищених виробничих стічних вод на технічні побутові потреби, тим більше, що регламент використання водних 
ресурсів на підприємствах молокопереробної промисловості дає змогу. Для цього ми пропонуємо конструкцію біоплато 3 вищими водними рослинами.

Біоплато являє собою споруду для біологічної доочистки стічних вод із природною аерацією й складається 3 двох блоків: інфільтраційного та поверхневого, розміщених каскадом.

Інфільтраційний блок - це біофільтр, розміщений у земляному котловані, глибиною близько 2 м, шириною 3-4 м, довжиною до 8 м, на дні якого знаходиться протифільтраційний екран зі спеціальної поліетиленової плівки (два шари) або кількох шарів глини. Поверх протифільтраційного екрану прокладається горизонтальний дренаж і так зване фільтруюче завантаження, в якості якого може служити щебінь, пісок, керамзит, гравій та інші насипні пористі матеріали. Горизонтальний дренаж забезпечує рух води, що очищається, крізь зарості вищих водних рослин та коренезаселений шар фільтруючого завантаження. Висота фільтруючого завантаження 0,7-0,8 метра. На поверхні фільтра висаджуються вищі водні рослини: очерет, рогіз, комиш із густотою посадки очерету звичайного та комишу озерного $35-45$ рослин на $1 \mathrm{~m}^{2}$, рогозу широколистого та вузьколистого - 25-30 рослин. На початку біоплато висаджують очерет, далі комиш, а потім - рогозу. Вздовж біоплато ми рекомендуємо насаджувати аїр болотний, що має високу бактерицидну здатність і повністю нейтралізує неприємний запах. Глибина води в блоці не менше 20-40 см у літній період, 40-60 см взимку.

Самопливна фільтрація забезпечується роботою колектора, закладеного в основі фільтруючої товщі біоплато 3 протилежної дефлектору сторони. Інфільтраційний блок - біоінженерна споруда $з$ горизонтальною фільтрацією; на поверхню блоку вода не потрапляе, й очищення відбувається за допомогою кореневої системи рослин, розвиток якої проходить у товщі фільтруючого завантаження.

Після проходження (протягом двох діб) води через інфільтраційний блок вода самопливом, через колодязь із регулятором рівня, поступає до другого ступеня очисних споруд - поверхневого біоплато.

Поверхневе біоплато являє собою котлован, довжиною 20-30 м і шириною 3-4 м, із невеликим нахилом до 0,005 м по дну. Також на дні знаходиться протифільтраційний екран. Зверху нього закладається грунт на висоту 0,6 м, що також засаджується ВВР, у тій же послідовності, що й на фільтраційному біоплато.

Оптимальна глибина занурення рослин у воду - 0,5-1 метрів.

У результаті очищення в біоінженерних спорудах якість стічних вод досягає вимог для використання на технічно-побутові потреби. Після очищення води в системі $з$ двох БІС вода направляється до басейну накопичувача чистої води, а потім (за допомогою насоса) по мережі трубопроводів надходить на технічно-побутові потреби.

Основні характеристики стічних вод міськмолокозаводу після доочищення на біоплато з вищими водними рослинами

\begin{tabular}{|c|c|c|c|}
\hline \multirow{2}{*}{ Показник } & \multirow{2}{*}{$\begin{array}{c}\text { Характерис- } \\
\text { тика води, } \\
\text { що } \\
\text { подається } \\
\text { на біоплато }\end{array}$} & \multicolumn{2}{|c|}{$\begin{array}{c}\text { Величина } \\
\text { показника }\end{array}$} \\
\hline & & $\begin{array}{c}\% \\
\text { очистки }\end{array}$ & $\begin{array}{c}\text { після } \\
\text { очистки }\end{array}$ \\
\hline $\begin{array}{c}\text { Температура, } \\
{ }^{\circ} \mathrm{C}\end{array}$ & $15-25$ & - & $5-25$ \\
\hline $\mathrm{pH}$ & $8,5-9,0$ & - & $7,5-8,5$ \\
\hline $\begin{array}{c}\text { Кислотність, } \\
\text { мг/л } \\
\end{array}$ & 128 & - & - \\
\hline $\begin{array}{c}\text { Зважені речо- } \\
\text { вини, мг/л }\end{array}$ & 50,4 & $80-99$ & $\begin{array}{c}1- \\
10,08 \\
\end{array}$ \\
\hline $\begin{array}{c}\text { Сухий } \\
\text { залишок, мг/л } \\
\end{array}$ & 380 & - & - \\
\hline $\begin{array}{c}\mathrm{XCK} \\
\mathrm{Cr}, \mathrm{M} \Gamma \\
\mathrm{O}_{2} / \mathrm{дm}^{3} \\
\end{array}$ & 1100 & $65-95$ & $55-385$ \\
\hline $\begin{array}{c}\text { БСК }_{5}, \mathrm{м} Г \\
\mathrm{O}_{2} / \text { дм }^{3} \\
\end{array}$ & 148,9 & $65-95$ & $7,4-52$ \\
\hline $\begin{array}{c}\text { БСК повн }_{\text {пон }}, \mathrm{MГ} \\
\mathrm{O}_{2} / \mathrm{дм}^{3} \\
\end{array}$ & 595,7 & $65-95$ & $\begin{array}{l}27,9- \\
208,5 \\
\end{array}$ \\
\hline $\begin{array}{l}\text { Загальний } \\
\text { азот, мг/л }\end{array}$ & 29 & $50-75$ & $\begin{array}{c}7,25- \\
14,5 \\
\end{array}$ \\
\hline Аміак, мг/л & 0 & - & - \\
\hline Жири, мг/л & 0,25 & 91-99 & $\begin{array}{c}0,0025- \\
0,0225 \\
\end{array}$ \\
\hline СПАР & 0,0007 & 90 & 0,00007 \\
\hline Хлориди, мг/л & 150 & - & - \\
\hline Фосфати, мг/л & 0,5 & $50-70$ & $\begin{array}{c}0,15- \\
0,25\end{array}$ \\
\hline Амоній, мг/л & 0,7 & $60-90$ & $\begin{array}{c}0,07- \\
0,28\end{array}$ \\
\hline
\end{tabular}

Висновки. Отже, у результаті проведених досліджень була розроблена конструкція біоплато 3 вищими водними рослинами (очерет звичайний, комиш озерний, рогіз вузьколистий, рогіз широколистий, аїр болотний) для доочищення стічних вод молокозаводу, з подальшим використанням їх для потреб підприємства. 


\section{БІБЛІОГРАФІЯ}

1. Джсихией В. С. Екологія та охорона навколишнього природного середовища: Навч. пос. для студ. вуз. - К. : Знання, 2000. -203 с.

2. Потіш А. Ф., Медвідб А. Г. Екологія: теоретичні основи і практикум : Навч. пос. для студ. вузів. - Львів : Магнолія, 2006, 2008. - 324 с.

3. Кравець В. В., Мережкко О. І. Спосіб біологічного очищення поверхневих вод. Патент. 3550345/SU // Промислова вартість. - 1983. - № 3.

4. Регіональна програма охорони довкілля, раціонального використання природних ресурсів та забезпечення екологічної безпеки з урахуван- ням регіональних пріоритетів Полтавської області на 2012-2015 роки (Програма «Довкілля$2015 ») .-174 \mathrm{c}$.

5. Справочник проектировщика. Канализация населенных мест и промышленных предприятий / Н. И. Лихачев, И. И. Ларин, С. А. Хаскин [и др.] ; под общ. ред. В. Н. Самохина. - 2-е изд., перераб. и доп. - М. : Стройиздат, 1981. - 639 с.

6. Таварткіладзе I. Економне очищення стоків // Харчова і переробна промисловість. - 1999.№ 9. - C. 26-27. 